\title{
The avid competitors of memory inflation
}

\author{
Leila Abassi ${ }^{1}$ and Luka Cicin-Sain ${ }^{1,2,3,4 *}$
}

1. Department of Vaccinology and Applied Microbiology, Helmholtz Centre for Infection Research ( $\mathrm{HZI})$

2. Cluster of Excellence RESIST (EXC 2155), Hannover Medical School (MHH)

3. Centre for Individualised Infection Medicine (CIIM), a joint venture of $\mathrm{HZI}$ and $\mathrm{MHH}$

4. German Centre for Infection Research (DZIF), Hannover-Braunschweig site

*corresponding author

${ }^{1}$ E-mail: Luka.Cicin-Sain@helmholtz-hzi.de, Phone: 0531 6181-4616

E-mail: Leila.Abassi@helmholtz-hzi.de, Phone: 0531 6181-5013

\section{Address}

Department of Vaccinology and Applied Microbiology, Helmholtz Centre for Infection Research (HZI),

Inhoffenstraße 7, 38124 Braunschweig, Germany

Declaration of interest: No competing interests

\section{ABSTRACT:}

Cytomegaloviruses (CMV) coevolve with their hosts and latently persist in the vast majority of adult mammals. Therefore, persistent T-cell responses to CMV antigens during virus latency offer a fascinating perspective on the evolution of the T-cell repertoire in natural settings. We addressed here the life-long interactions between CMV antigens presented on MHC-I molecules and the CD8 T-cell response. We present the mechanistic evidence from the murine model of CMV infection and put it in context of clinical laboratory results. We will highlight the remarkable parallels in T-cell responses between the two biological systems, and focus in particular on memory inflation as a result of competitive processes, both between viral antigenic peptides and between T-cell receptors on the host's cytotoxic lymphocytes. 


\section{Introduction}

Cytomegalovirus (CMV) is the paradigmatic exponent of the ß-subfamily of herpesviruses. CMV is a globally ubiquitous herpesvirus with a prevalence about $50 \%$ in most developed countries and $80 \%$ or higher in developing ones [1]. While the primary infection in most immunocompetent hosts is mild or asymptomatic, CMV may cause diverse clinical conditions in the susceptible host. Infections that occur during pregnancy are the most common infectious cause of severe and lasting damage to the developing embryo, including deafness, blindness and learning disabilities [2]. Additionally, CMV may cause life-threatening disease in immunocompromised adults, such as transplant recipients or AIDS patients [3]. A life-long latent persistence in the infected host is a defining characteristic of herpesviruses. Latency is defined as a dormant state, in which the virus maintains minimum gene expression, but can reactivate its lytic replication cycle and cause disease. If the immune system of a host is suppressed, either naturally or iatrogenically, CMV may reactivate, causing interstitial pneumonia, gastroenteritis, transplant rejections or graft versus host disease [3]. The control of CMV infection is mediated by adaptive Immune responses, and in particular the $\mathrm{T}$ cell response. Namely, transfer of CMV specific T-cells to immunocompromised patients was sufficient to control the virus and subdue clinical symptoms in numerous studies [4-6]. On the other hand, a vaccine against CMV is still not available [7], despite numerous efforts [8]. In this review, we would like to summarize the latest inputs regarding the dynamics of $\mathrm{T}$ cell responses upon CMV infection, and the forces shaping the expansion of T-cell clones in competition with each other.

\section{$\mathrm{T}$ cell responses upon $\mathrm{CMV}$ infection in human and mice}

The human cytomegalovirus (HCMV) induces a T-cell response that is sustained for life and formidably strong $[9,10]$. In HCMV seropositive healthy people, the fraction of HCMV specific cells may exceed $10 \%$ of the memory compartments [10], indicating that a strong T-cell response may be necessary to prevent virus reactivation. Therefore, it is reasonable to assume that only a vaccine that elicits robust $\mathrm{T}$-cell responses in combination with humoral immunity might provide sufficient immune protection against HCMV. Most of the approved vaccines induce antibody responses, which target the pathogens in the intercellular space and not within infected cells. However, some viruses, including HCMV, can also spread between cells through cell-cell contact without ever leaving a cell [11]. Therefore, antibody responses against HCMV may not be enough, because only a vaccine that efficiently targets HCMV in infected cells by cellular immunity would provide sufficient immune control of HCMV. In that case, understanding what is required for the induction of the uniquely strong T-cell responses against HCMV would be crucial for the successful development of any HCMV vaccine.

The mechanistic study of T-cell responses, their dynamics and cause-effect relationships requires an experimental model. Unfortunately, HCMV cannot be studied directly in an animal host, because its replication is restricted to human cells due to millions of years of coevolution. Therefore, CMV infection has been experimentally studied by analyzing the infection of animals with coevolving CMV species that naturally infect them [12]. The mouse cytomegalovirus (MCMV) model of infection is a well-established system that has been used for decades to study the mechanisms of the immune response to CMV infection [13,14]. Functional and phenotypical similarities of the T-cell response to HCMV and MCMV have been documented in numerous studies. For instance, CMV-specific CD8 T cell populations in humans and mice show an expansion of two main primed T cell subsets, effector and central memory cells [15], during the acute and latent infection $[16,17]$. Both HCMV and MCMV specific CD8 T cells display a terminally 
differentiated effector phenotype in latently infected hosts $[18,19]$, characterized by a loss of CD62L, CD27 and CD28 from the cell surface with a concomitant expression of KLRG1 [19-22]. Likewise, in both HCMV and MCMV infection, these effector cells retain some functionality, as they are able to respond to antigen restimulation by cytokine secretion $[21,23]$ and thus they are clearly distinguishable from exhausted T-cells induced by other chronic infections [24]. Finally, CMV-specific effector $T$ cells show poor proliferative responses upon restimulation, and this also is a shared trait of mice and men [20,25]. In conclusion, the CD8 T cells induced by MCMV show sufficient similarities to the HCMV situation to warrant the use of the MCMV model to study the mechanisms of T-cell induction and maintenance upon CMV infection.

\section{Phenotype of CMV specific T cell responses}

Memory inflation is an ongoing accumulation of antigen-specific CD8 T cells upon CMV infection [26-28], which was first identified in the lungs of latently infected mice [18], and later documented by dynamic follow-up of T-cell responses in the peripheral blood [29]. Importantly only some MCMV-specific cells are inflationary, whereas other ones induce conventional responses that contract upon the resolution of the acute infection [17,21]. The difference in the long-term outcome of these two subsets is not only a difference in population size, but also in the expression pattern of surface receptors, cytokines and transcription factors [30]. While the inflationary and the conventional T-cells show distinct outcomes in the long-term, the initial responses are remarkably similar. Upon naïve cell priming, both the inflationary and the non-inflationary cells expand to form populations of short-lived effectors and memory-precursor effector cells, which both contribute to virus clearance [21,31,32]. It is only after the resolution of the primary infection, that the differences between inflationary and conventional cells become obvious. The population of conventional $\mathrm{T}$ cells contracts, leading to the generation of a small pool of antigen specific cells with the classical central-memory phenotype (CD62 $\mathrm{L}^{\mathrm{hi}}, \mathrm{CCR} 7^{\mathrm{hi}}, \mathrm{Bcl}-2^{\mathrm{hi}}, \mathrm{CD} 27^{\mathrm{hi}}$, and KLRG1 $\left.{ }^{\mathrm{lo}}\right)$. On the other hand, the inflationary cells retain a spectrum of phenotypes, from the central-memory, via transitional ones (e.g. $\mathrm{CD} 62 \mathrm{~L}^{\mathrm{lo}} \mathrm{CD} 27^{\mathrm{hi}}$ ) to terminally differentiated short-lived effector cells $\left(\mathrm{CD} 62 \mathrm{~L}^{\mathrm{lo}}, \mathrm{CD}^{2} 7^{\mathrm{lo}}, \mathrm{CD} 28^{\mathrm{lo}}, \mathrm{Bcl} 2^{\mathrm{lo}}, \mathrm{CD} 127^{\mathrm{lo}}, \mathrm{KLRG} 1^{\mathrm{hi}}\right)$, where the more mature subsets are increasingly more abundant (Figure 1). A similar distribution of CD27 and CD28 phenotypes is also observed in CD8 T cells recognizing immunodominant HCMV antigens in healthy people [33] or in transplant recipients [34]. Likewise, CD8 T cells against defined immunodominant HCMV epitopes are more abundant with age [9,35], although the broad response to HCMV peptide pools did not show this increase [36]. The early dynamics of T-cell responses to HCMV remain largely unknown due to the lack of specific symptoms, but the available evidence points to substantial overlaps in the phenotype, function and dynamics of cellular immune responses to MCMV and HCMV in the chronic phase. Therefore, the mechanistic insights from the mouse model may inform us about the dynamics and the maintenance of human T cell response to HCMV.

\section{Role of antigen competition during memory inflation}

The overall size of inflationary responses is determined by inoculum size during primary infection [37] and robust virus replication during primary infection results in a larger latent MCMV load [38]. Furthermore, non-hematopoietic cells are a major site of MCMV latency [32,39] and memory inflation, as opposed to the primary response, depends on antigen that is presented on nonhematopoietic cells $[40,41]$. Taken together, the evidence strongly suggests that antigens from latently infected cells fuels the memory inflation [42,43]. Memory inflation is strongly influenced by a plethora of factors, including cytokine signaling or the balance between cell proliferation and survival, just to name a few, but for reasons of space and focus, this review will specifically 
contemplate the effects of pMHC-TCR interaction. This interaction is key to understand memory inflation, which is not an overall ongoing expansion of CMV specific $\mathrm{T}$ cells, but rather the expansion of T-cells recognizing a few optimal antigenic peptides at the expense of other, subdominant ones [44,45]. Competition for antigen between inflationary CD8+ $T$ cells upon MCMV infection has been described in several studies. Infecting mice with recombinant MCMV viruses encoding immunodominant exogenous epitopes leads to strong inflationary responses against these epitopes and a reduction of inflationary $\mathrm{T}$ cells recognizing endogenous MCMV antigens [46-48]. Likewise, MCMVs with mutated immunodominant peptides induce stronger $\mathrm{T}$ cell responses against subdominant epitopes or responses to novel epitopes that are not immunogenic in wild-type MCMV infection [49,50]. However, antigen competition does not occur in all experimental systems. A recombinant MCMV expressing the immunodominant epitope SIINFEKL did not reduce memory inflation of CD8+ $T$ cells specific for endogenous MCMV epitopes when used in coinfection with MCMV WT (lacking the SIINFEKL epitope) [48]. This observation argues that competition for $\mathrm{T}$ cell responses occurs only if antigens are present in the same virus genome, and likely in the same latently infected cell, where the most robust antigenic peptides become the agents of memory inflation.

So what exactly determines the robustness of an antigen in the induction of memory inflation? The epitope's availability for processing by the constitutive proteasome is a key requirement for memory inflation [51,52], likely because the latently infected non-hematopoietic cells do not express the immunoproteasome, unless activated by interferons. Another major factor is the binding affinity of T-cell receptors (TCR) to peptide-MHC complexes (pMHC) on target cells, evidenced by stronger inflationary responses to high-affinity than to low-affinity epitopes, if expressed at the exactly same position [53]. These effects are intuitive. A pMHC that is firmly bound by the cognate TCR will induce T-cells more efficiently at each binding than an epitope that TCRs rapidly disengage from. Finally, the context of gene expression defines the size of responses, because the same epitope induces stronger inflationary responses when expressed in the context on an immediate-early (IE) gene, than in the context of genes expressed later in the virus cycle $[47,51,53]$. The early gene expression as a determinant of immunodominance is likely a reflection of peptide abundance on $\mathrm{PMHC}$. IE transcripts are more common during latency [54]. Therefore, T-cells recognizing an IE epitope will be engaged more frequently, which will select them over antigen specific $T$ cells recognizing epitopes expressed in early or late genes.

\section{Role of TCR competition during memory inflation}

Numerous host factors determine the size of the T-cell response as well. TCR diversity is a result of somatic recombination and selection during T-cell maturation in the thymus [55]. Therefore, clonally different CD8 T cells may still recognize the same pMHC complex, albeit with different affinities of binding. Early upon infection, a polyclonal TCR repertoire is recruited, in part to the same epitope. The frequency of naïve precursor T cells defines the hierarchy of primary CD8 responses to MCMV, but it does not determine which epitopes become inflationary later on [56]. Therefore, memory inflation depends on factors that occur after priming. A robust response of early primed $\mathrm{KLRG} 1^{10}$ cells defines the size of the inflationary $\mathrm{T}$ cell pool [31], as these cells generate a robust pool of memory cells, which later feed the inflationary population [20,57]. Multiple clonotypes simultaneously undergo Ag-driven proliferation during latent MCMV infection, resulting in stable CD8+ T cell repertoires, which appear to be dominated by persistent clonotypes [58]. However, a more detailed analysis of responding T-cells identifies a highly dynamic evolution of the responding repertoires based on TCR avidity. TCRs with higher affinity of binding prevail 
over those with lower affinity of response in the initial months post infection [31,59], because a higher affinity leads to higher functional avidity of responses. Therefore, cells that react to less peptide are naturally selected to proliferate over those that need more target peptides to become activated. However, long-term monitoring of inflationary T-cell responses at single cell level paints a different picture. Over time, the lower avidity cells expand in the population, whereas high-avidity T cells assume more mature phenotypes [59]. It has been proposed that this is due to an earlier onset of terminal differentiation and senescence of inflationary T-cell clones with high-avidity responses [59]. Therefore, the long-term outcome of memory inflation is a reverse evolution of the repertoire, first towards a higher affinity repertoire, and then away from it $[59,60]$.

It is intriguing that the concept of reverse evolution is also supported by some observations of clinical samples, where large populations of inflationary T-cells in a patient are typically characterized by low avidity responses, whereas people with smaller populations of T-cells recognizing the same epitope have typically higher avidities of responding cells [59]. On the other hand, the emergence of high-affinity TCR clones against an immunodominant HCMV epitope has been described to occur specifically in older people, contrasting the idea of reverse evolution in clinical conditions [61]. Likewise, functional avidity of dominant TCR clones was in general higher than the avidity of subdominant clones in another study [62]. Therefore, we would like to propose that the low avidity of large responder populations does not necessarily reflect reverse evolution of low-avidity $T$ cells, because it may also be a reflection of viral peptides competing for T-cell attention. In this scenario, in a patient with an HLA-I haplotype that provides a definite advantage to T-cells recognizing one HCMV peptide and little competition against other populations, these cells will strongly expand, and even TCRs with lower avidities will be recruited to the inflationary pool. However, if another patient has an HLA-I constellation where the same epitope can be recognized, but needs to compete for inflationary responses with co-dominant epitopes, only $\mathrm{T}$ cells clones with higher affinity of TCR binding to $\mathrm{pMHC}$ will be selected. Therefore, the overall population of responding cells to this epitope will be smaller, but will consist of $T$ cells with higher affinity TCRs (Figure 2). The result would then be an inverse correlation of TCR avidity and inflationary population size, in line with the clinical observation [59]. While this has not been formally shown in an experimental system, the second scenario may provide an additional explanation for the clinically observed phenomenon.

\section{Conclusion}

While CMV infection alters permanently the composition of the T-cell compartment in a latently infected host [45], the effects on its functionality remain remarkably modest $[63,64]$. This phenomenon is likely a reflection of virus-host coevolution, where the presence of a latent CMV may even result in improved immune function $[65,66]$. Therefore, the complex dynamics of T-cell responses to this virus may serve to inform us on requirements for a healthy immune response and persistence of functional antigen specific cells. This is not merely a question of academic interest. Understanding such requirements would pave the way to the design of better vaccines, which may optimally induce cellular immune responses and T-cell memory. Whether CMV should be the vector used in such approaches [67] is an open question, but the tremendous advances of our understanding of $\mathrm{T}$ cell immunity achieved by studying CMV infection remain indisputable. 


\section{Acknowledgements}

We thank Fawad Khan for his help during the literature search. This research was supported by the German Centre for Infection Research (DZIF) through the grant 07.817 and the Deutsche Forschungsgemeinschaft under Germany's Excellence Strategy - EXC 2155 "RESIST" - Project ID 39087428 and the research projects FOR2830.

\section{References}

1. Adland E, Klenerman P, Goulder P, Matthews P: Ongoing burden of disease and mortality from HIVICMV coinfection in Africa in the antiretroviral therapy era. Frontiers in Microbiology 2015, 6.

2. Emery V, Lazzarotto $\mathrm{T}$ : Cytomegalovirus in pregnancy and the neonate [version 1; peer review: 2 approved]. F1000Research 2017, 6.

3. Griffiths PD: Burden of disease associated with human cytomegalovirus and prospects for elimination by universal immunisation. Lancet Infect Dis 2012, 12:790-798.

4. Walter EA, Greenberg PD, Gilbert MJ, Finch RJ, Watanabe KS, Thomas ED, Riddell SR: Reconstitution of cellular immunity against cytomegalovirus in recipients of allogeneic bone marrow by transfer of T-cell clones from the donor. $N$ Engl $J$ Med 1995, 333:1038-1044.

5. Einsele H, Roosnek E, Rufer N, Sinzger C, Riegler S, Loffler J, Grigoleit U, Moris A, Rammensee HG, Kanz L, et al.: Infusion of cytomegalovirus (CMV)-specific T cells for the treatment of CMV infection not responding to antiviral chemotherapy. Blood 2002, 99:3916-3922.

6. Cwynarski K, Ainsworth J, Cobbold M, Wagner S, Mahendra P, Apperley J, Goldman J, Craddock C, Moss PA: Direct visualization of cytomegalovirus-specific T-cell reconstitution after allogeneic stem cell transplantation. Blood 2001, 97:1232-1240.

7. Gerna G, Lilleri D: Human Cytomegalovirus Congenital (cCMV) Infection Following Primary and Nonprimary Maternal Infection: Perspectives of Prevention through Vaccine Development. Vaccines (Basel) 2020, 8.

8. Krause PR, Bialek SR, Boppana SB, Griffiths PD, Laughlin CA, Ljungman P, Mocarski ES, Pass RF, Read JS, Schleiss MR, et al.: Priorities for CMV vaccine development. Vaccine 2013, 32:4-10.

9. Komatsu H, Sierro S, A VC, Klenerman P: Population analysis of antiviral T cell responses using MHC class I-peptide tetramers. Clin Exp Immunol 2003, 134:9-12.

10. Sylwester AW, Mitchell BL, Edgar JB, Taormina C, Pelte C, Ruchti F, Sleath PR, Grabstein $\mathrm{KH}$, Hosken NA, Kern F, et al:: Broadly targeted human cytomegalovirus-specific CD4+ and CD8+ T cells dominate the memory compartments of exposed subjects. $J$ Exp Med 2005, 202:673-685.

11. Silva MC, Schröer J, Shenk T: Human cytomegalovirus cell-to-cell spread in the absence of an essential assembly protein. Proc Natl Acad Sci U S A 2005, 102:2081-2086.

12. Reddehase MJ, Lemmermann NAW: Mouse Model of Cytomegalovirus Disease and Immunotherapy in the Immunocompromised Host: Predictions for Medical Translation that Survived the "Test of Time". Viruses 2018, 10.

13. Quinnan GV, Manischewitz JE, Ennis FA: Cytotoxic T lymphocyte response to murine cytomegalovirus infection. Nature 1978, 273:541-543. 
14. Reddehase MJ, Koszinowski UH: Significance of herpesvirus immediate early gene expression in cellular immunity to cytomegalovirus infection. Nature 1984, 312:369371.

15. Sallusto $F$, Lenig D, Förster R, Lipp M, Lanzavecchia A: Two subsets of memory $\mathbf{T}$ lymphocytes with distinct homing potentials and effector functions. Nature 1999, 401:708-712.

16. Vieira Braga FA, Hertoghs KM, van Lier RA, van Gisbergen KP: Molecular characterization of HCMV-specific immune responses: Parallels between CD8(+) T cells, CD4(+) T cells, and NK cells. Eur J Immunol 2015, 45:2433-2445.

*17. Munks MW, Cho KS, Pinto AK, Sierro S, Klenerman P, Hill AB: Four distinct patterns of memory CD8 $T$ cell responses to chronic murine cytomegalovirus infection. $J$ Immunol 2006, 177:450-458.

This study shows that CD8 T cell responses to dominant MCMV epitopes concomittantly display four distinct kinetics during acute and latent infection, where only some of the responses are inflationary.

18. Holtappels R, Pahl-Seibert MF, Thomas D, Reddehase MJ: Enrichment of immediate-early 1 (m123/pp89) peptide-specific CD8 T cells in a pulmonary CD62L(lo) memoryeffector cell pool during latent murine cytomegalovirus infection of the lungs. $J$ Virol 2000, 74:11495-11503.

19. Appay V, Dunbar PR, Callan M, Klenerman P, Gillespie GM, Papagno L, Ogg GS, King A, Lechner F, Spina CA, et al.: Memory CD8+ T cells vary in differentiation phenotype in different persistent virus infections. Nat Med 2002, 8:379-385.

*20. Snyder CM, Cho KS, Bonnett EL, van Dommelen S, Shellam GR, Hill AB: Memory Inflation during Chronic Viral Infection Is Maintained by Continuous Production of ShortLived, Functional T Cells. Immunity 2008, 29:650-659.

Authors demonstrate that inflationary MCMV-specific T cells are terminally differentiated cells, which require antigen recognition for maintenance in the latently infected host and whose proliferation depends on a supply of cells from a less differentiated pool.

21. Sierro S, Rothkopf R, Klenerman P: Evolution of diverse antiviral CD8+ T cell populations after murine cytomegalovirus infection. Eur $\mathrm{J}$ Immunol 2005, 35:1113-1123.

22. Ouyang Q, Wagner WM, Voehringer D, Wikby A, Klatt T, Walter S, Müller CA, Pircher H, Pawelec G: Age-associated accumulation of CMV-specific CD8+ T cells expressing the inhibitory killer cell lectin-like receptor G1 (KLRG1). Exp Gerontol 2003, 38:911920.

23. Hertoghs KML, Moerland PD, van Stijn A, Remmerswaal EBM, Yong SL, van de Berg PJEJ, van Ham SM, Baas F, ten Berge IJM, van Lier RAW: Molecular profiling of cytomegalovirus-induced human CD8+ T cell differentiation. The Journal of clinical investigation 2010, 120:4077-4090.

24. Cicin-Sain L, Arens R: Exhaustion and Inflation at Antipodes of T Cell Responses to Chronic Virus Infection. Trends Microbiol 2018, 26:498-509.

25. van Leeuwen EM, Gamadia LE, Baars PA, Remmerswaal EB, ten Berge IJ, van Lier RA: Proliferation requirements of cytomegalovirus-specific, effector-type human CD8+ T cells. J Immunol 2002, 169:5838-5843.

26. Klenerman P: The (gradual) rise of memory inflation. Immunol Rev 2018, 283:99-112.

27. O'Hara GA, Welten SP, Klenerman P, Arens R: Memory T cell inflation: understanding cause and effect. Trends Immunol 2012, 33:84-90.

28. Klenerman P, Oxenius A: T cell responses to cytomegalovirus. Nat Rev Immunol 2016, 16:367-377. 
29. Karrer U, Sierro S, Wagner M, Oxenius A, Hengel H, Koszinowski UH, Phillips RE, Klenerman P: Memory inflation: continuous accumulation of antiviral CD8+ T cells over time. $J$ Immunol 2003, 170:2022-2029.

30. van den Berg SPH, Pardieck IN, Lanfermeijer J, Sauce D, Klenerman P, van Baarle D, Arens R: The hallmarks of CMV-specific CD8 T-cell differentiation. Medical Microbiology and Immunology 2019, 208:365-373.

*31. Baumann NS, Welten SPM, Torti N, Pallmer K, Borsa M, Barnstorf I, Oduro JD, Cicin-Sain L, Oxenius A: Early primed KLRG1- CMV-specific T cells determine the size of the inflationary T cell pool. PLoS Pathog 2019, 15:e1007785.

This study shows that high-avidity T-cells predominanty expand during memory inflation and that the size of the inflationary $T$ cell pool depends on the number of cells that are primed early upon infection and by the size of the $\mathrm{T}_{\mathrm{CM}}$ compartment in the pool of inflationary antigen-specific cells.

32. Contreras NA, Sitnik KM, Jeftic I, Coplen CP, Cicin-Sain L, Nikolich-Zugich J: Life-long control of cytomegalovirus (CMV) by T resident memory cells in the adipose tissue results in inflammation and hyperglycemia. PLoS Pathog 2019, 15:e1007890.

33. Komatsu H, Inui A, Sogo T, Fujisawa T, Nagasaka H, Nonoyama S, Sierro S, Northfield J, Lucas $M$, Vargas $A$, et al:: Large scale analysis of pediatric antiviral CD8+ $T$ cell populations reveals sustained, functional and mature responses. Immunity \& ageing : I \& A 2006, 3:11-11.

34. Cantisán S, Torre-Cisneros J, Lara R, Rodríguez-Benot A, Santos F, Gutiérrez-Aroca J, Gayoso I, González-Padilla M, Casal M, Rivero A, et al.: Age-dependent association between low frequency of CD27/CD28 expression on pp65 CD8+ T cells and cytomegalovirus replication after transplantation. Clin Vaccine Immunol 2009, 16:1429-1438.

35. Hosie L, Pachnio A, Zuo J, Pearce H, Riddell S, Moss P: Cytomegalovirus-Specific T Cells Restricted by HLA-Cw*0702 Increase Markedly with Age and Dominate the CD8(+) T-Cell Repertoire in Older People. Front Immunol 2017, 8:1776.

36. Jackson SE, Sedikides GX, Okecha G, Wills MR: Generation, maintenance and tissue distribution of $\mathrm{T}$ cell responses to human cytomegalovirus in lytic and latent infection. Med Microbiol Immunol 2019, 208:375-389.

37. Redeker A, Welten SP, Arens R: Viral inoculum dose impacts memory T-cell inflation. Eur J Immunol 2014, 44:1046-1057.

38. Reddehase MJ, Balthesen M, Rapp M, Jonjić S, Pavić I, Koszinowski UH: The conditions of primary infection define the load of latent viral genome in organs and the risk of recurrent cytomegalovirus disease. J Exp Med 1994, 179:185-193.

39. Seckert CK, Renzaho A, Tervo HM, Krause C, Deegen P, Kuhnapfel B, Reddehase MJ, Grzimek NK: Liver sinusoidal endothelial cells are a site of murine cytomegalovirus latency and reactivation. $J$ Virol 2009, 83:8869-8884.

40. Torti N, Walton SM, Brocker T, Rulicke T, Oxenius A: Non-hematopoietic cells in lymph nodes drive memory CD8 $\mathrm{T}$ cell inflation during murine cytomegalovirus infection. PLoS Pathog 2011, 7:e1002313.

41. Seckert CK, Schader SI, Ebert S, Thomas D, Freitag K, Renzaho A, Podlech J, Reddehase MJ, Holtappels R: Antigen-presenting cells of haematopoietic origin prime cytomegalovirus-specific CD8 T-cells but are not sufficient for driving memory inflation during viral latency. Journal of General Virology 2011, 92:1994-2005.

42. Welten SPM, Baumann NS, Oxenius A: Fuel and brake of memory T cell inflation. Medical Microbiology and Immunology 2019, 208:329-338.

43. Seckert CK, GriessI M, Buttner JK, Scheller S, Simon CO, Kropp KA, Renzaho A, Kuhnapfel B, Grzimek NK, Reddehase MJ: Viral latency drives 'memory inflation': a unifying 
hypothesis linking two hallmarks of cytomegalovirus infection. Med Microbiol Immunol 2012, 201:551-566.

44. Cicin-Sain L: Cytomegalovirus memory inflation and immune protection. Med Microbiol Immunol 2019, 208:339-347.

45. Cicin-Sain L, Brien JD, Uhrlaub JL, Drabig A, Marandu TF, Nikolich-Zugich J: Cytomegalovirus infection impairs immune responses and accentuates T-cell pool changes observed in mice with aging. PLoS Pathog 2012, 8:e1002849.

46. Snyder C, Turula H, Farrington L, Grey F, Hill A: Competition for antigen selects T cell responses that undergo memory inflation and maintains clonal dominance during MCMV infection (P6091). 2013, 190:173.172-173.172.

*47. Dekhtiarenko I, Jarvis MA, Ruzsics Z, Čičin-Šain L: The context of gene expression defines the immunodominance hierarchy of cytomegalovirus antigens. $J$ Immunol 2013, 190:3399-3409.

Authors developed recombinant MCMV vectors expressing a single CD8 T cell epitope fused to different CMV genes, and showed that $T$ cell immunodominance and responses depend on the context of antigen expression.

48. Farrington LA, Smith TA, Grey F, Hill AB, Snyder CM: Competition for Antigen at the Level of the APC Is a Major Determinant of Immunodominance during Memory Inflation in Murine Cytomegalovirus Infection. 2013, 190:3410-3416.

49. Ebert S, Lemmermann NA, Thomas D, Renzaho A, Reddehase MJ, Holtappels R: Immune control in the absence of immunodominant epitopes: implications for immunotherapy of cytomegalovirus infection with antiviral CD8 T cells. Med Microbiol Immunol 2012, 201:541-550.

50. Holtappels R, Simon CO, Munks MW, Thomas D, Deegen P, Kühnapfel B, Däubner T, Emde SF, Podlech J, Grzimek NK, et al.: Subdominant CD8 T-cell epitopes account for protection against cytomegalovirus independent of immunodomination. $J$ Virol 2008, 82:5781-5796.

51. Dekhtiarenko I, Ratts RB, Blatnik R, Lee LN, Fischer S, Borkner L, Oduro JD, Marandu TF, Hoppe S, Ruzsics Z, et al.: Peptide Processing Is Critical for T-Cell Memory Inflation and May Be Optimized to Improve Immune Protection by CMV-Based Vaccine Vectors. PLoS Pathog 2016, 12:e1006072.

52. Hutchinson S, Sims S, O'Hara G, Silk J, Gileadi U, Cerundolo V, Klenerman P: A dominant role for the immunoproteasome in CD8+ $T$ cell responses to murine cytomegalovirus. PLoS One 2011, 6:e14646.

**53. Borkner L, Sitnik KM, Dekhtiarenko I, Pulm AK, Tao R, Drexler I, Cicin-Sain L: Immune Protection by a Cytomegalovirus Vaccine Vector Expressing a Single Low-Avidity Epitope. J Immunol 2017, 199:1737-1747.

Authors showed that even low-avidity antigenic epitopes may mediate robust inflationary $\mathrm{T}$ cell responses that are protective against virus challenge. Furthermore, the study shows that inflationary responses against various CMV antigens are in competition with each other, and winners are defined by both TCR avidity of binding to pMHC and by the context of expression.

54. Simon CO, Holtappels R, Tervo HM, Bohm V, Daubner T, Oehrlein-Karpi SA, Kuhnapfel B, Renzaho A, Strand D, Podlech J, et al.: CD8 T cells control cytomegalovirus latency by epitope-specific sensing of transcriptional reactivation. $J$ Virol 2006, 80:1043610456.

55. Schober K, Buchholz VR, Busch DH: TCR repertoire evolution during maintenance of CMV-specific T-cell populations. Immunol Rev 2018, 283:113-128.

56. Akue AD, Lee J-Y, Jameson SC: Derivation and maintenance of virtual memory CD8 T cells. Journal of immunology (Baltimore, Md. : 1950) 2012, 188:2516-2523. 
57. Welten SPM, Yermanos A, Baumann NS, Wagen F, Oetiker N, Sandu I, Pedrioli A, Oduro JD, Reddy ST, Cicin-Sain L, et al.: Tcf1(+) cells are required to maintain the inflationary $T$ cell pool upon MCMV infection. Nat Commun 2020, 11:2295.

**58. Smith CJ, Venturi V, Quigley MF, Turula H, Gostick E, Ladell K, Hill BJ, Himelfarb D, Quinn KM, Greenaway HY, et al.: Stochastic Expansions Maintain the Clonal Stability of CD8(+) T Cell Populations Undergoing Memory Inflation Driven by Murine Cytomegalovirus. J Immunol 2020, 204:112-121.

In this study, authors describe a remarkable clonal stability of inflationary CD8 T cells upon MCMV infection, but also the occasional emergence and expansion of rare clonotypes in this population.

**59. Schober K, Voit F, Grassmann S, Müller TR, Eggert J, Jarosch S, Weißbrich B, Hoffmann $P$, Borkner L, Nio E, et al.: Reverse TCR repertoire evolution toward dominant lowaffinity clones during chronic CMV infection. Nat Immunol 2020, 21:434-441.

In this study, they explore the evolution and affinity of TCR repertoire during cytomegalovirus infection by using single cell and bulk TCR sequencing and structural affinity methods of CMVspecific T cells. The study concludes that high avidity TCRs are dominant early upon infection, but low avidity responders prevail in the very long-term.

60. Redeker A, Arens R: 'Reverse evolution' in T cell biology. Nat Immunol 2020, 21:360-362. 61. Schwanninger A, Weinberger B, Weiskopf D, Herndler-Brandstetter D, Reitinger S, Gassner C, Schennach H, Parson W, Würzner R, Grubeck-Loebenstein B: Age-related appearance of a CMV-specific high-avidity CD8+ T cell clonotype which does not occur in young adults. Immun Ageing 2008, 5:14.

62. Trautmann L, Rimbert M, Echasserieau K, Saulquin X, Neveu B, Dechanet J, Cerundolo V, Bonneville M: Selection of T cell clones expressing high-affinity public TCRs within Human cytomegalovirus-specific CD8 T cell responses. J Immunol 2005, 175:61236132.

63. Furman D, Jojic V, Sharma S, Shen-Orr SS, Angel CJ, Onengut-Gumuscu S, Kidd BA, Maecker HT, Concannon P, Dekker CL, et al.: Cytomegalovirus infection enhances the immune response to influenza. Sci Transl Med 2015, 7:281ra243.

64. Marandu TF, Oduro JD, Borkner L, Dekhtiarenko I, Uhrlaub JL, Drabig A, Kröger A, NikolichZugich J, Cicin-Sain L: Immune Protection against Virus Challenge in Aging Mice Is Not Affected by Latent Herpesviral Infections. J Virol 2015, 89:11715-11717.

65. Smithey MJ, Venturi V, Davenport MP, Buntzman AS, Vincent BG, Frelinger JA, NikolichŽugich J: Lifelong CMV infection improves immune defense in old mice by broadening the mobilized TCR repertoire against third-party infection. Proc Natl Acad Sci U S A 2018, 115:E6817-e6825.

66. Barton ES, White DW, Cathelyn JS, Brett-McClellan KA, Engle M, Diamond MS, Miller VL, Virgin HWt: Herpesvirus latency confers symbiotic protection from bacterial infection. Nature 2007, 447:326-329.

67. Ynga-Durand MA, Dekhtiarenko I, Cicin-Sain L: Vaccine Vectors Harnessing the Power of Cytomegaloviruses. Vaccines (Basel) 2019, 7. 
The authors declare that they have no conflicts of interest.
Leila Abassi
Luka Cicin-Sain

Conflict of Interest
\[ \begin{array}{l}\text { The authors declare that they have no conflicts of interest. } \\ \text { Leila Abassi } \\ \text { Luka Cicin-Sain }\end{array} \]

The authors declare that they have no conflicts of interest.
Leila Abassi
Luka Cicin-Sain

Conflict of Interest

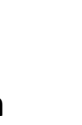

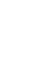

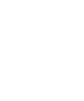

The authors declare that they have no conflicts of interest.
Leila Abassi
Luka Cicin-Sain
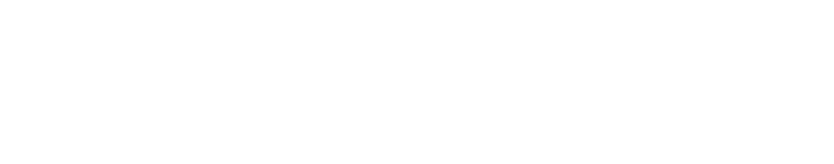


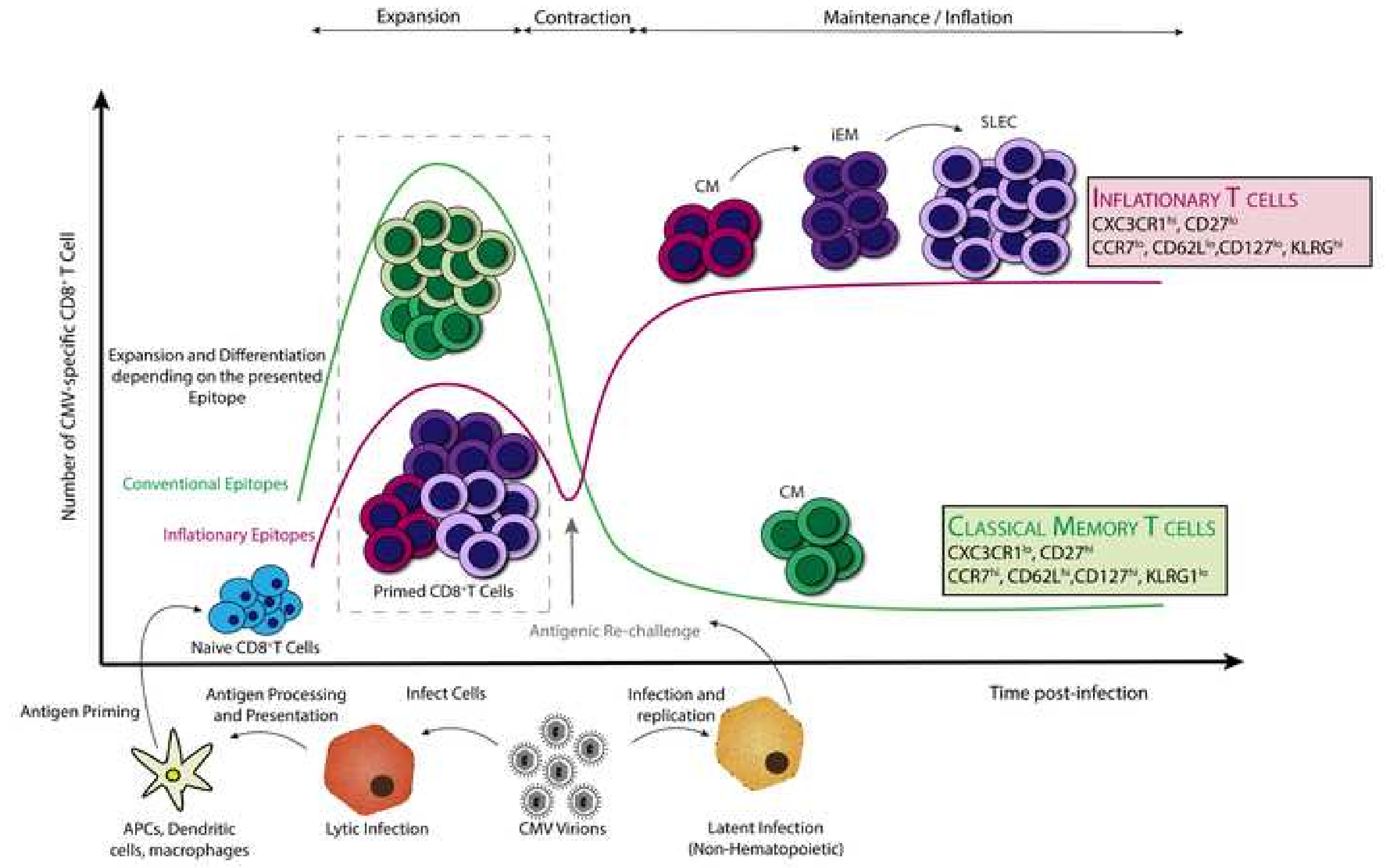




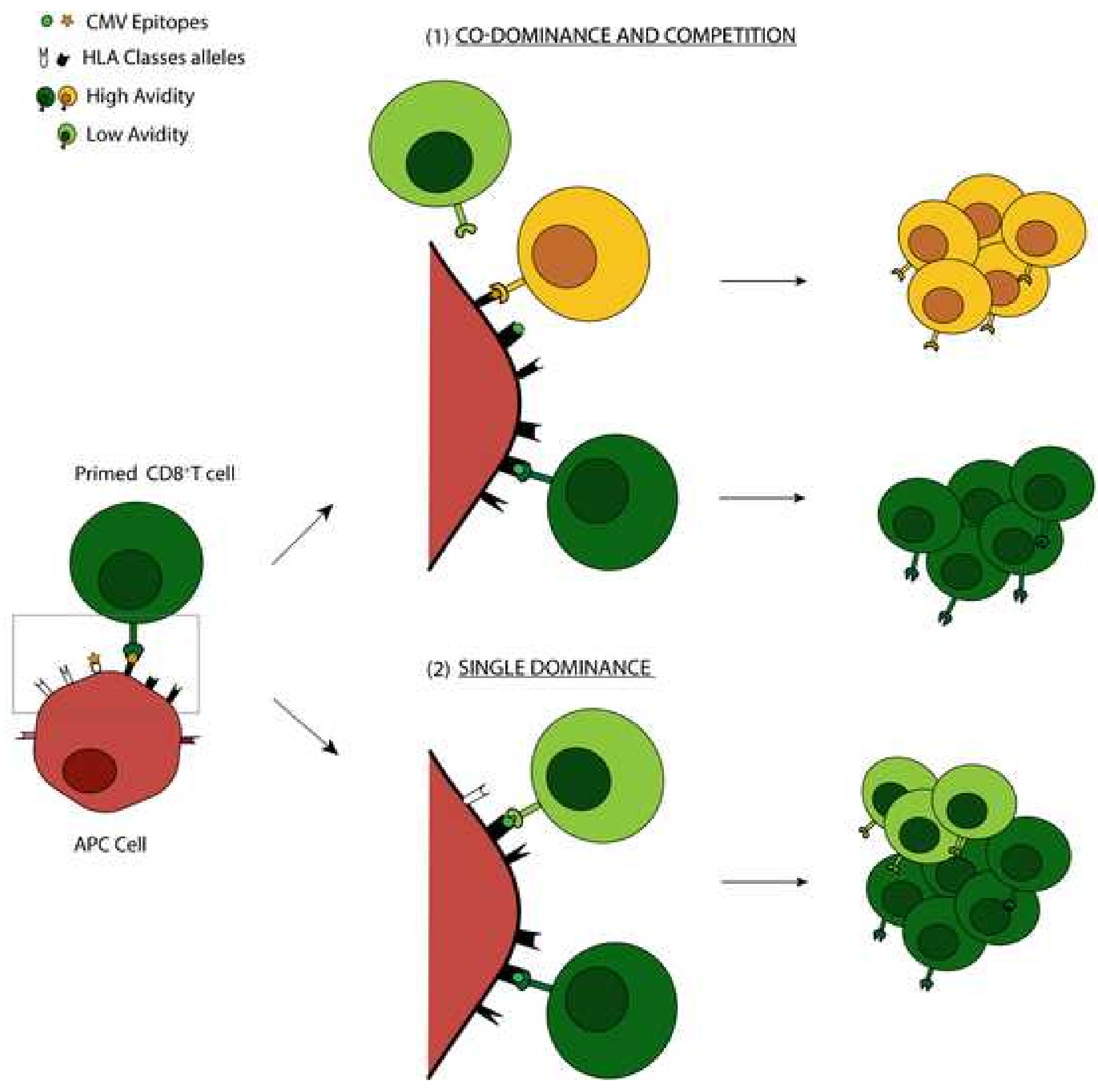


Response to Reviewers

Reviewers
We added to the reference list the descriptions to the referenced literature indicated by one or two
stars. We added to the reference list the descriptions to the referenced literature indicated by one or two
stars. (n)

do the refence list the descriptions to the referenced literature indicated by one or two

(1)

(1) 